\begin{tabular}{cc}
\hline International Journal of Engineering \& Technology, $7(2.29)(2018) 798-803$ \\
SPC & Website: www.sciencepubco.com/index.php/IJET \\
Research paper & International Journal of Engineering \& Technology \\
\hline
\end{tabular}

\title{
Light Shelf as a Daylighting System in a Tropical Climate Office Space
}

\author{
Abimaje, Joshua ${ }^{1 *}$, Mohd Zin Bin Kandar², Dodo Yakubu Aminu \\ ${ }^{I}$ Department Of Architecture, Universiti Teknologi Malaysia / Federal Polytechnic, Idah, Nigeria \\ ${ }^{2,3}$ Department Of Architecture, Universiti Teknologi Malaysia \\ *Corresponding Author E-Mail: Arcabim@Gmail.Com
}

\begin{abstract}
Daylighting is a passive design strategy for lighting office spaces given the fact that offices operate within daytime, usually between 8:00 am to 5:00 pm which corresponds to the period of daylight availability. Daylight is abundant in the tropics, free and has no negative impact on the environment. It has positive physiological and psychological effect on the man as well as good colour rendering. Ironically, despite the abundant availability and the merits of daylighting especially in the tropics, it is not fully utilized. A light shelf is one of the innovative daylighting systems that can be employed to improve office spaces daylighting performance. Therefore, the focus of this study is the application of light shelf as a daylighting system in government offices in Malaysia. This study was carried out through literature search on thirteen disciplines. The disciplines were building and environment, energy, and building, renewable and sustainable energy, energy conservation in Building, lighting research and technology, energy conservation and Management, Solar energy, renewable energy, indoor and built environment, energy policy, energy and buildings, renewable energy, and applied energy. Data were obtained from Science Direct, Web of Science, Scopus and Conference Proceedings. This was done by typing in keywords such as daylighting, light shelf, office spaces, visual performance, tropical climate, and Malaysia. The review was from 1986 to 2016 to cover the length and breadth of the study area for the past 30 years. This work includes previous review and empirical works. Attention was equally given to the methodologies and context of the work. The result of this study showed the poor daylighting performance of government office spaces in Malaysia. The daylighting in these offices is either too low as a result of the use of excessive external shading devices to reduce interior heat gain or too high due to over glazed wall for aesthetics and daylighting. Consequent upon these is inadequate daylighting illuminance, non-uniform illuminance distribution, and glare. This brings about visual discomfort. Also, the study revealed that light shelf as an innovative daylighting lighting system could improve the daylighting performance of these office spaces. The effectiveness of light shelf depends on the latitude, reflectance of light shelf material, the angle of inclination, its depth, mounting position among others. However, there exists little work on the effect of the depth of light shelf and the variation of its distance from the ceiling on the daylight performance of government office spaces in Malaysia. This paper, therefore, recommends investigation on the effect of the depth of light shelf and the variation of its distance from the ceiling on daylighting performance of government office spaces in Malaysia.
\end{abstract}

Keywords: daylighting; light shelf; office spaces; visual performance; tropical climate; Malaysia.

\section{Introduction}

Buildings are responsible for $40 \%$ of the world energy consumption (1-9). At the global level, 25 to $40 \%$ of this energy used, is for artificial lighting $(10,11)$. When the level of energy consumption is narrowed down to Asian countries, the trend of energy consumption is not different (2). The study on energy consumption of commercial buildings in South Asia as reported by (Loewen et al.,) indicated $233 \mathrm{Kwh} / \mathrm{m}^{2} / \mathrm{yr}$. This same study revealed that Malaysia as a country consumes $269 \mathrm{Kwh} / \mathrm{m}^{2} / \mathrm{yr}$ which is the highest among the countries studied. This finding is similar to that of (12). Malaysia standard recommends energy consumption of less than $135 \mathrm{Kwh} / \mathrm{m}^{2} / \mathrm{yr}$. However, (13) observed almost $100 \%$ of energy consumption above this standard. (14) Conducted a study, result of this indicated $58 \%, 20 \%, 19 \%$ and $3 \%$ of energy consumption in government offices in Malaysia is for cooling and ventilation, lighting, office equipment and others respectively. Similarly, (15) observed that $57 \%$ of energy consumption in office buildings is for cooling and heating, $19 \%$ is for lighting, $18 \%$ for pumps and the remaining $6 \%$ for other services. These studies show a significant level of energy consumption for lighting in Malaysian office buildings.

The need for energy efficiency in buildings arose from the realization of increased energy cost, over-reliance on fossil fuel and the attendant environmental degradation. For instance, (16) gave $80 \%$, $13.5 \%$ and $6.5 \%$ of fossil fuel, renewable energy, and nuclear energy consumption respectively globally. Fossil fuel burning for energy production emits $\mathrm{CO}$, $\mathrm{CO}$ and other greenhouse gases (3). The emission of $(680.39 \mathrm{~g})$ of carbon dioxide, $(5.67 \mathrm{~g})$ of sulphur dioxide and (2.27) of nitrogen oxide will be prevented from each saving of a kWh of energy (17). Therefore, the manner in which energy is currently being generated and utilized especially in the office buildings is unsustainable.

Daylighting is a passive design strategy for lighting office buildings (18) given the fact that offices operate within daytime, usually between 8:00 am to 5:00 pm which corresponds to the period of daylight availability (19). Daylight is abundant in the tropics (20, 21) free and has no negative impact on the environment (22). It 
has positive physiological and psychological effect on the man as well as good colour rendering (19). (23) also submitted that daylighting enhances performance compared to artificial lighting. Ironically, despite the abundant availability and the merits of daylighting especially in the tropics, it is not fully utilized (22). (24) opined that this anomaly is due to improper fenestration design. (22) carried out a study on building facade design for daylighting quality in typical government office buildings in Malaysia, the result shows that only illuminance of 70lux was achieved at a distance of $3.5 \mathrm{~m}$ from the window. On the contrary, in another study by Lim and Heng (19), a sharp contrast in illuminance level between places close to the window and places farther away was observed. This resulted in non-uniform illuminance distribution, glare among other things which led to the rejection on daylighting and the occupants resorted to artificial lighting.

Lim et al. (22) conducted a study on a typical office building in Malaysia. The result from the finding indicated the challenge of daylight through side light since illuminance decreases with depth or distance for a sidelight space (22). There are various innovative daylighting systems such as a light tube, light shelf, louver among others as stated by $(25,26)$. A light shelf is a very effective daylight device as it redirects light deep into the building (2732). The focus of this study is the application of light shelf as a daylighting system. (33) Stated that light shelf allows uniform and deep penetration of daylighting into office spaces. Also, several scholars such $(19,33,34)$ have conducted empirical studies on the daylighting performance of light shelf using measurement and simulation in several places, but there exists little work on the compilation of these works for proper understanding especially concerning Malaysia. This paper, therefore, through literature search aims at achieving good daylighting in government office spaces in Malaysia using the light shelf. It identified daylighting performance criteria, the daylighting performance in government offices in Malaysia and the use of light shelf for improving the daylighting performance of government office spaces in Malaysia.

\section{Methodology / Materials}

This study was carried out through literature search on thirteen disciplines. These disciplines were building and environment, energy, and building, renewable and sustainable energy, energy conservation in a building, lighting research and technology, energy conservation and management, solar energy, renewable energy, building and environment, indoor and built environment, energy policy, renewable energy, and applied energy. Data were obtained from Science Direct, Web of Science, Scopus and Conference Proceedings. This was done by typing in keywords such daylighting, light shelf, office spaces, visual performance, tropical climate. The review was from 1986 to 2016 to cover the length and breadth of the work that has been done in this area for the past 30years. This work includes previous review and empirical works. Attention was equally given to the methodologies and context on the work..

\section{Results and Findings Discussion}

Table 1 shows several daylighting performance criteria such as work plane illuminance, surface illuminance, illuminance distribution uniformity, daylight factor, daylight ratio, glare analysis among others as observed by scholars such as $(19,21,22,32,34-$ 52).

In Table 2, Freewan, Shao (53) used the different geometry of ceiling while the light shelf was made horizontal. The geometry of ceiling used includes curve and chamfer. The essence of this was to investigate how different ceiling geometry affect the daylighting performance of light shelf. In a related study, Freewan (54) varied the geometry of light shelf with a curved ceiling. Horizontal, angular and curved light shelves were tested for their daylighting performance on curved ceiling.

Meresi (23) investigated the effect of the mounting height of light shelf on illuminance uniformity. The light shelf mounting position and its effect on the illuminance of the interior shapes were equally investigated by Lim and Heng (19). Ponmalar and Ramesh (34), studied the effect of the different light shelf on their surface reflectance using aluminium, mirror, etc.

Pen \& Cheung, (2014) conducted a study of the different geometry of clerestory and concluded that wide top clerestory enhances good illuminance. Berardi and Anaraki (33) submitted that the depth of light shelf has a positive effect on useful daylight illuminance.

\subsection{Parameter for Daylighting Performance}

Work plane illuminance (WPI) is one of the indicators for evaluating daylight quality. At the work plane of an office space, (34) opined that the basic illuminance level should be 450lux. The Chartered Institute of Building Services Engineers (55), asserted that the acceptable range is $300-500$ lux for offices regarding work plane illuminance and added that 5001x is needed for reading and writing in an office building as work plane illuminance. Dubois (46) opined work plane illuminance lower than 100lux is considered too dark for paperwork as well as computer work. The Malaysian Standard and Green Building Index $(56,57)$ gave 300 to 400 lux as a range of the required office illuminance level base on the requirement of the various tasks to be performed in an office space. (22) Stated absolute work plane illuminance of 500lux as being too bright for computer work. Berrutto, Fontoynont (50) indicated an average preferred horizontal illuminance of 325lux for computer work and 425-500lx for general work. This variation in work plane illuminance suggests that different task requires different illuminance. The work plane level or height also varies base on the nature of the work. However, for office space, it ranges from 600-750mm from the floor level (34).

\begin{tabular}{|l|l|l|l|}
\hline Author(s) & Discipline & study & Criteria \\
\hline $\begin{array}{l}\text { Ponmalar \& Ramesh } \\
(2014)\end{array}$ & $\begin{array}{l}\text { Energy Engi- } \\
\text { neering }\end{array}$ & Energy efficient building design and estimation of energy savings from daylighting in Chennai. & $\begin{array}{l}\text { Work plane } \\
\text { illuminance }\end{array}$ \\
\hline Dubois, (2001a) & $\begin{array}{l}\text { Work plane } \\
\text { illuminance }\end{array}$ \\
\hline Lim et al., (2012) & $\begin{array}{l}\text { Building \& } \\
\text { environment }\end{array}$ & Building façade design for daylighting quality in a typical government office building \\
\hline Berutto et al., (1979) & Right Light & Effect of temperature \& light source types (natural/artificial) on visual comfort t appraisal. & $\begin{array}{l}\text { Work plane } \\
\text { illuminance }\end{array}$ \\
\hline Dubois, (2001a) & $\begin{array}{l}\text { Energy \& } \\
\text { Building de- } \\
\text { sign }\end{array}$ & $\begin{array}{l}\text { Impact of solar shading devices on daylight quality: simulations with radiance. } \\
\text { Work plane } \\
\text { illuminance }\end{array}$ \\
\hline Lim et al., (2012) & $\begin{array}{l}\text { Building \& } \\
\text { environment }\end{array}$ & $\begin{array}{l}\text { Building façade design for daylighting quality in a typical government office } \\
\text { Building de- } \\
\text { sign }\end{array}$ & Impact of solar shading devices on Daylight quality: simulation with radiance. \\
\hline Dubois, (2001b) & $\begin{array}{l}\text { Work plane } \\
\text { illuminance }\end{array}$ \\
\hline
\end{tabular}




\begin{tabular}{|c|c|c|c|}
\hline Author(s) & Discipline & study & Criteria \\
\hline $\begin{array}{l}\text { Lim \& Hamdan, } \\
(2010)\end{array}$ & & Daylight \& users' response in high rise open plan office: a case study of Malaysia & $\begin{array}{l}\text { Work plane } \\
\text { illuminance } \\
\text { ratio }\end{array}$ \\
\hline Lim \& Heng, (2016) & $\begin{array}{l}\text { Building \& } \\
\text { Environment }\end{array}$ & Dynamic internal light shelf for tropical daylighting in high-rise office buildings. & $\begin{array}{l}\text { Work plane } \\
\text { illuminance } \\
\text { ratio, Glare }\end{array}$ \\
\hline $\begin{array}{l}\text { Illuminating Engi- } \\
\text { neering (1993) }\end{array}$ & & $\begin{array}{l}\text { Lighting Handbook: Reference and Application ( } 8^{\text {th }} \text { ed.) Illuminating Engineering Society of } \\
\text { North America IESNA). }\end{array}$ & $\begin{array}{l}\text { Surface } \\
\text { luminance } \\
\text { ratio }\end{array}$ \\
\hline CIBSE, (1994) & & Chartered Institute of Building Services Engineers. & $\begin{array}{l}\text { Surface } \\
\text { luminance } \\
\text { ratio }\end{array}$ \\
\hline Dubois, (2001a) & & Impact of solar shading devices on daylight Quality: simulations with radiance. & $\begin{array}{l}\text { Surface } \\
\text { luminance } \\
\text { ratio } \\
\end{array}$ \\
\hline Lim et al., (2012) & $\begin{array}{l}\text { Building \& } \\
\text { environment }\end{array}$ & Building façade design for daylighting quality in a typical government office building & distribution \\
\hline $\begin{array}{l}\text { Haqparast \& Maleki } \\
\text { (2014) }\end{array}$ & & Daylighting \& daylight simulation & $\begin{array}{l}\text { Uniformity } \\
\text { distribution }\end{array}$ \\
\hline Assaf, (1997) & Right light & components of innovative glazing performance. & $\begin{array}{l}\text { Uniformity } \\
\text { distribution }\end{array}$ \\
\hline CIBSE, (2004) & & Energy efficiency in buildings. The Chartered Institute of Building Engineering. London. & $\begin{array}{l}\text { Uniformity } \\
\text { distribution }\end{array}$ \\
\hline Bulow-Hube (2001) & & Energy Efficient Window systems: Effects on energy use and daylight in Buildings. & $\begin{array}{l}\text { Uniformity } \\
\text { distribution }\end{array}$ \\
\hline Lim, (2011) & & Internal shading for efficient tropical daylighting in high-rise open plan office & $\begin{array}{l}\text { Uniformity } \\
\text { distribution }\end{array}$ \\
\hline $\begin{array}{l}\text { Rungta \& Singh } \\
(2011)\end{array}$ & & Design guide: horizontal shading devices and light shelves. & $\begin{array}{l}\text { Daylight } \\
\text { factor }\end{array}$ \\
\hline Robbins, (1985) & & Daylighting. design and analysis. & $\begin{array}{l}\text { Daylight } \\
\text { factor }\end{array}$ \\
\hline Wu \& Ng, (2003) & $\begin{array}{l}\text { Light research } \\
\& \text { Technology }\end{array}$ & A review of the development of daylighting in schools. & $\begin{array}{l}\text { Daylight } \\
\text { factor }\end{array}$ \\
\hline Mill \& Borg (1999). & & Trends in recommended illuminance levels & $\begin{array}{l}\text { Daylight } \\
\text { factor }\end{array}$ \\
\hline Mohammed (2014) & & Appropriate opening and layout for daylighting of office spaces. & $\begin{array}{l}\text { Daylight } \\
\text { factor }\end{array}$ \\
\hline $\begin{array}{l}\text { Lim \& Hamdan, } \\
(2010)\end{array}$ & $\begin{array}{l}\text { Engineering } \\
\text { Science \& } \\
\text { building }\end{array}$ & Daylight \& users' response in high rise open plan office: a case study of Malaysia & $\begin{array}{l}\text { Daylight } \\
\text { factor }\end{array}$ \\
\hline Lim et al., (2009) & & $\begin{array}{l}\text { Effect of solar shading, fenestration \& Room geometry on office building Energy efficiency in } \\
\text { hot, humid tropic. }\end{array}$ & $\begin{array}{l}\text { Daylight } \\
\text { factor }\end{array}$ \\
\hline $\begin{array}{l}\text { Tzempelikos \& } \\
\text { Athienitis (2007) }\end{array}$ & Solar energy & The impact of shading design and control on building cooling and lighting demand. & $\begin{array}{l}\text { Daylight } \\
\text { factor }\end{array}$ \\
\hline Fadzil \& Sia (2004) & $\begin{array}{l}\text { Building \& } \\
\text { Environment }\end{array}$ & Sunlight control and daylight distribution analysis & $\begin{array}{l}\text { Daylight } \\
\text { factor }\end{array}$ \\
\hline
\end{tabular}

Table 2: Some selected articles on the variables used in the past studies

\begin{tabular}{|c|c|c|c|c|}
\hline \multirow{2}{*}{ Criteria } & \multirow{2}{*}{ AUTHOR } & \multicolumn{2}{|c|}{$\begin{array}{l}\text { VARIABLES } \\
\end{array}$} & \multirow[t]{2}{*}{ Result } \\
\hline & & Independent & Independent & \\
\hline Work plane Illuminance & Freewan, (2008) & Horizontal light shelf & ceiling geometry & Improved work plane illuminance \\
\hline Illuminance Uniformity & Freewan (2010) & curved ceiling & Light shelf geometry & curved light shelf performed better \\
\hline Illuminance Uniformity & Meresi (2016) & Light shelf & mounting height & $\begin{array}{l}\text { Higher mounting affect illuminance } \\
\text { uniformity }\end{array}$ \\
\hline Illuminance & $\begin{array}{l}\text { Ponmalar \& Ramesh } \\
\text { (2014) }\end{array}$ & Light shelf & Light shelf Reflectance & $\begin{array}{l}\text { Mirror finished light surface shelf } \\
\text { performed surface shelf performed } \\
\text { better }\end{array}$ \\
\hline Illuminance & Pen \& Cheung (2014) & Light shelf & Clerestory geometry & Wide top clerestory geometry enhanced \\
\hline Illuminance & Lim \& Heng (2016) & Light shelf & Mounting Position & Mounting position affect Illuminance \\
\hline $\begin{array}{l}\text { Useful daylight Illumi- } \\
\text { nance }\end{array}$ & $\begin{array}{l}\text { Bererdi \& Anaraki } \\
\text { (2015) }\end{array}$ & Light shelf & Depth of light shelf & $\begin{array}{l}\text { Depth enhances useful daylight illumi- } \\
\text { nance }\end{array}$ \\
\hline
\end{tabular}

Work Plane Illuminance uniformity is important to keep away places from contrast and better lighting quality. Commission on International illumination (58) and (55) stated that the acceptable illuminance uniformity (minimum/average) over any task area should be lower than 0.8. Many lighting standards require a uniformity ratio of 0.8 (minimum/average) or 0.7 (minimum/maximum). However, some research indicated that a ratio of 0.5 (minimum/maximum) might even be acceptable (59). WPI Uniformity ratio is the ratio of minimum work plane illuminance to average work plane illuminance, i.e., daylight distribution ((22).
Higher Uniformity Ratio indicates better daylight distribution (40, 60 ). Uniformity ratio of 0.1 is poor daylight distribution (19). Many researchers posited that there is a relationship between surface luminance and visual comfort $(44,48,59)$. Luminance values of all room surface should be lower than $850 \mathrm{~cd} / \mathrm{m}^{2}$. Whereas, the adjacent surfaces for paper and reading tasks should not be higher than $255 \mathrm{~cd} / \mathrm{m}^{2}$ (61). According to Dubois (59), surface luminance lower than $30 \mathrm{~cd} / \mathrm{m}^{2}$ is not acceptable. Surface luminance between $30-500 \mathrm{~cd} / \mathrm{m}^{2}$ is considered preferable. Surface luminance above $1000 \mathrm{~cd} / \mathrm{m}^{2}$ is considered too bright in the visual 
fields, and surface luminance above $2000 \mathrm{~cd} / \mathrm{m}^{2}$ is too bright for all surfaces in the room (59)

Luminance ratio demonstrates the brightness of window on the other surfaces of interior surfaces. Therefore, it can be calculated by dividing window luminance by average internal surface luminance. Great contrast in luminance causes glare problem. Thus, some guidelines are recommended for luminance ratio among task area, (61) recommended that luminance ratio should be lower than 40 (61). (55) Showed similar recommendation with IES. Also, Dubois (59) indicated that luminance ratio between any points within the field of view should be lower than 20 (59).

Illuminance uniformity distribution measures daylighting quality (22). It measures how light varies from point one to the other on a plane surface. For better visual performance, some level of evenness through the task plane is necessary. Poor quality of light and visual discomfort may result if the eye is made to adjust too fast to a variety of light levels $(62,63)$. Uniformity describes the evenness of illuminance distribution across space, desk or working area. It is calculated as the ratio of the minimum illumination to the average illuminance over the specified task areas, while the diversity is the ratio of the minimum to the maximum illuminance over the core area of the working plane. The Chartered Institution of Building Services Engineers (55) defined two types of measurement to study the lighting variations that is, uniformity and diversity (CIBSE, 2004). Slater and Boyce (1990) investigated the acceptable illuminance uniformity on a desk for different tasks. Many tasks were performed under different uniformity ratios and illuminance levels, and numerical verification tasks. The uniformity ratio on the desk was found to be 0.7 for all tasks with smooth variation and could be 0.5 for tasks performed at the central part of the desk.

Fontoynont (64) discussed the applicability of uniformity and glare standard on daylight. This study revealed that the uniformity ratio for daylight could be much lower than the ones required for artificial lighting. Occupants are more tolerant to glare and nonuniform distribution from daylight sources than from artificial light sources. Moreover, the required illuminance may be lower with daylight than with artificial lighting (63-65).

The recommended uniformity levels, minimum to average, by (55) and (61) are within a range of 0.5-0.8. The (55) standard required a uniform level over the task area of 0.8 , while the overall uniformity could be much less than 0.8 . Dubois considered that uniformity level minimum/maximum of 0.5 is acceptable and 0.7 is preferable. (64) Showed that variability from daylight sources is preferable and gives a sense of cheerfulness and more attractiveness. Moreover, he stated that uniformity could not be a real criterion in the case of daylight. The quality issue borders on the minimization of illuminance contrast in a given space. It is necessary that illuminance is distributed within the interior spaces especially at the work plane instead of concentrating at a point which always results in serious contrast and visual discomfort (22). To avoid sharp illuminance contrast or low illuminance uniformity distribution, $(36,44)$ opined that shading devices should be used to prevent direct exposure to the sky components and direct sunlight patches. (22) also observed that light shelf has the potential to reduce the undesirable effect of direct sunlight in an interior space and improve daylight uniformity distribution.

The daylight factor (66) is a daylighting performance variable related to interior illuminance level used under overcast sky condition $(37,51)$. It is the ratio of interior illuminance level to exterior illuminance level under unobstructed sky expressed as a percentage (51).

The DF is used as a performance indicator for evaluating the space potential for daylight utilization and by implication a daylighting performance indicator for room space daylight efficiency. Daylight factor does not change with changes in exterior illuminance, but for calculating daylight factor, external illuminance data should be available. Daylight levels are different in every country $(43,49)$. This suggests why there exist variation in daylighting performance standards in various nations. For instance, Mohammed (67) carried out a study on appropriate opening and layout for daylighting of office spaces at the Eastern Mediterranean University. The finding from this study concluded that $2 \%$ Daylight Factor (66) is a common minimum standard while the $1.5 \%-3.0 \%$ and 1.0-3.5 are ranges of daylight factor based on Malaysian standard (56) and Green Building Index (57) of Malaysia respectively. Day Factor above $6.00 \%$ will cause glare and the thermal problem (22). However, daylight factor should be between 2-5\% for providing preferable interior illuminance, Dubois (60) asserted. As stated earlier by $(43,49)$, daylight levels are different in every country. These differences may be traceable to the fact that the daylight factor is a model that emanated from CIE sky standard which is that of temperate while Malaysian sky condition is predominantly intermediate tropical sky as observed by $(22,68)$. This suggests that the sky condition is a cardinal factor when using daylight factor as a daylighting performance criterion.

Glare problem is caused by extremely uneven daylighting distribution in space. Vision is the most developed human sense thus visual comfort required not only adequate illuminance level but also glare must be controlled, and pattern of contrast should be appropriate (69). Windows without shading devices being installed become a source of glare because of the high difference in illuminance level near windows, as a result of direct sun rays, and far less illuminance at the rare space in deep office especially in the afternoon. Shading devices help reduce the sun patches on the working plane and offices' surfaces, thereby reducing glare, veiling reflections and the differences in the illuminance level on different parts of the office area.

For glare analysis, Guth Visual Comfort (VCP) and CIE Glare Index are usually employed (22). Guth VCP is to measure the percentage of people who would be satisfied with a particular view; while CIE Glare Index is a unitless Index of Visual Comfort which is used as an international standard. Guth VCP value of 65\% and CIE Glare Index Value of 19 are acceptable for sedentary conditions; Guth VCP value of $52 \%$ and CIE Glare index value of 22 are acceptable for transient conditions (47). Many building users close up their windows totally with blinds to avoid glare. As a result, the abundance of daylight in a tropical climate is yet to be utilized (38).

\subsection{Daylighting Performance of Office Space in Malay-} sia

Lim \&. Heng (70) observed that many office spaces in high-rise offices receive high indoor illuminance with non-uniform distribution and glare due to large glazed facade without shading devices. Areas which are few meters away from the wall were observed to be gloomy, while those close to the window received too much light and resulted in the glare. This made the condition unsuitable for work. In this study, it was noticed the many office users closed up their windows totally with blinds to avoid glare. This reduced daylight levels in the main body of the office hence its underutilization. This finding is consistent with that of (38). Therefore, the control and discomfort glare and harvesting of daylight is a critical issue to be considered to develop visually comfortable design solutions $(21,36,39,42)$.

Similarly, the result of the research conducted by (22) on lighting condition in 5 Malaysian government office buildings with different design typologies showed that internal daylight level in office buildings in Malaysia is insufficient despite the fact that the external illuminance is sometimes up 130 Klux in the tropics. This research further showed that several offices in Malaysia were developed for cost and space efficiency but with less emphasis on daylighting. Consequently, all the selected offices depended fully on electric lighting although there is sufficient external daylight availability in Malaysia. When the electric lights were switched off, all the five buildings did to meet Malaysian Standard (MS) (71) lighting recommendation. 


\subsection{Light Shelf as a Panacea}

Many types of research have been carried out by several scholars on a light shelf in different places under different climates. For instance, Freewan, Shao (53) researched optimization of light shelf performance by the modification of ceiling geometry in a highly luminous climate through physical model and radiance simulation software. Curved, chamfered, sloped up and sloped down ceiling were used for optimization. The result shows that the curved ceiling had a better illuminance distribution on the work plane. In a related study, (54) did work on maximizing the light shelf performance by investigating the effect of the curved ceiling and light shelf geometries. The horizontal light shelf was used as a base case. Light shelf with arch, internal curve, external curved and angled light shelf was investigated for their performance through physical measurement and radiance-based simulation. Although there was an improved performance with chamfered and internal curve, the external curve light shelf on curved ceiling geometry performed better than all regarding illuminance level. For uniformity level, chamfered and externally curved light shelf improved the uniformity level around the year compared to the horizontal light shelf as they increase the illuminance to a higher level in the rear part. Consequently, the illuminance level increased or decreased based on the light shelf geometry.

Ponmalar and Ramesh (34) Performed a daylighting analysis on light shelf system installed to save energy in office buildings in Tamil Nadu. At the preliminary stage, four different patterns of the light shelf of increasing diffused reflections were selected. The mirror finished light shelf had the highest illuminance, next is the light shelf with reflective surface.

Xue, Mak (72) investigated new static light shelf system design of clerestory windows for Hong Kong. This work focused on the influence of clerestory window structure on the performance of daylighting light shelves regarding interior illuminance level and uniformity distribution. The results show that the best clerestory window structure for Hong Kong is the one whose meniscus section is wide at the top and narrow at the bottom with a curvature angle ranging from $44.3^{\circ}$ to $90^{\circ}$.

Berardi and Anaraki (33) evaluated the impact of light shelves over the illuminance levels in a south facing office building in Toronto using Useful Daylight Illuminance as the metric of analysis. The depth of the light shelf was varied for this purpose. It was found out that the depth of light shelf improved the Useful Daylight Illuminance.

Meresi (23) examined a combination of devices that will exploit daylight in a typical Greek classroom with South orientation, providing visual comfort for its users as well as energy savings. The primary objective of this paper was to define the optimum characteristics of a light shelf and blinds mounted in the glazing of a classroom with south orientation in Greek to promote the exploitation of daylight. Light shelves were studied at two heights, $2.0 \mathrm{~m}$ and $2.2 \mathrm{~m}$ from the floor level, both horizontal and inclined at $10^{\circ}$ In all cases, light shelves improved the daylight uniformity.

Lim \& Heng (19) researched the internal light shelf for tropical daylighting in high-rise office buildings in Malaysia. This study concluded that light shelves with $900 \mathrm{~mm}$ clerestory height have higher indoor illuminance than light shelves with $600 \mathrm{~mm}$ clerestory heights. Therefore, clerestory height affects the daylighting performance of light shelf.

Although the preceding indicates the positive daylighting performance of light shelf, there is the need to explore further other light shelf design performance criteria for improved performance given the fact that most of the studies were carried in places of different latitude and sky conditions. Besides, the depth of illuminance of daylighting need to still be further extended deeper into deep office in a tropical climate with an intermediate sky since this affect light shelf performance.

\section{Conclusion}

This study identified the daylighting performance criteria such work plane illuminance, illuminance uniformity, the absence of glare, daylight factor which was used to evaluate the daylighting performance of government offices in Malaysia. The study revealed poor daylighting performance most of the Government office buildings. The excessive use of shading devices has sacrificed daylighting. On the other side, the elaborate use of glazed or curtain wall resulted in the admission of light beyond visual comfort level. Besides, most of the offices were designed and built based on cost and space efficiency without adequate consideration for daylighting visual comfort. The application of light shelf can improve daylighting performance of government offices in Malaysia. However, the efficiency of the light shelf is dependent on its geometry, reflectance, height, mounting position among others. Some of the light shelf performance criteria were investigated by scholars in different parts of the world, Malaysia inclusive. These studies revealed that little work has been done on the effect of varying the depth of the external and internal light shelves on office daylight performance. Also, the effect of varying the light shelf-ceiling height in deep office space in a tropical climate with intermediate sky needs investigation.

\section{References}

[1] Omrany H, Ghaffarianhoseini A, Ghaffarianhoseini A, Raahemifar K Tookey J. Application of passive wall systems for improving the energy efficiency in buildings: A comprehensive review. Renewable and Sustainable Energy Reviews. 2016;62:1252-69.

[2] Yang L, Yan H, Lam JC. Thermal comfort and building energy consumption implications-a review. Applied Energy. 2014;115:164-73.

[3] Alrubaih M, Zain MFM, Alghoul M, Ibrahim NLN, Shameri M, Elayeb O. Research and development on aspects of daylighting fundamentals. Renewable and Sustainable Energy Reviews. 2013;21:494-505.

[4] Costa A, Keane MM, Torrens JI, Corry E. Building operation and energy performance: Monitoring, analysis and optimisation toolkit. Applied Energy. 2013;101:310-6.

[5] Kavgic M, Mavrogianni A, Mumovic D, Summerfield A, Stevanovic Z Djurovic-Petrovic M. A review of bottom-up building stock models for energy consumption in the residential sector. Building and environment 2010;45(7):1683-97.

[6] Huberman N, Pearlmutter D. A life-cycle energy analysis of building materials in the Negev desert. Energy and Buildings. 2008;40(5):83748 .

[7] Scheuer C, Keoleian GA, Reppe P. Life cycle energy and environmental performance of a new university building: modeling challenges and design implications. Energy and buildings. 2003;35(10):1049-64.

[8] Wong NH, Cheong DKW, Yan H, Soh J, Ong C, Sia A. The effects of rooftop garden on energy consumption of a commercial building in Singapore. Energy and buildings. 2003;35(4):353-64.

[9] Geetha N, Velraj R. Passive cooling methods for energy efficien buildings with and without thermal energy storage-A review. Energy Education Science and Technology Part A: Energy Science and Research. 2012;29(2):913-46.

[10] Krarti M, Erickson PM, Hillman TC. A simplified method to estimate energy savings of artificial lighting use from daylighting. Building and Environment. 2005;40(6):747-54.

[11] Chirarattananon S, Chaiwiwatworakul P, Pattanasethanon S. Daylight availability and models for global and diffuse horizontal illuminance and irradiance for Bangkok. Renewable Energy. 2002;26(1):69-89.

[12] Yang L, Lam JC, Tsang CL. Energy performance of building envelopes in different climate zones in China. Applied Energy. 2008;85(9):800-17.

[13] Loewen J, Levine M, Busch J. ASEAN-USAID Building Energy Conservation Project: Final Report-Audit. Vol III Berkeley, Lawrence Berkeley Laboratory, University of California. 1992.

[14] Sadrzadehrafiei S, Mat KSS, Lim C. Energy consumption and energy saving in Malaysian office buildings. Models and Methods in Applied Sciences. 2011

[15] Saidur R. Energy consumption, energy savings, and emission analysis in Malaysian office buildings. Energy Policy. 2009;37(10):4104-13.

[16] Asif M, Muneer T. Energy supply, its demand and security issues for developed and emerging economies. Renewable and Sustainable Energy Reviews. 2007;11(7):1388-413.

[17] LANCASHIRE DS, FOX AE. Lighting: the way to building efficiency. Consulting-specifying engineer. 1996:34-6.

[18] Cohen R, Ruyssevelt P, Abuebid M. Passive solar design of a montessori primary-school. Energy Conservation in Building-the achievement of. 2012;50:78-84 
[19] Lim Y-W, Heng C. Dynamic internal light shelf for tropical daylighting in high-rise office buildings. Building and Environment. 2016;106:15566.

[20] Mohd Hamdan A. The influence of roof form and interior cross section on daylighting in the atrium spaces in Malaysia. Doctor of Philosophy, University of Manchester. 1996.

[21] Fadzil SFS, Sia S-J. Sunlight control and daylight distribution analysis: the KOMTAR case study. Building and Environment. 2004;39(6):713-

[22] Lim Y-W, Kandar MZ, Ahmad MH, Ossen DR, Abdullah AM. Building façade design for daylighting quality in typical government office building. Building and Environment. 2012;57:194-204.

[23] Meresi A. Evaluating daylight performance of light shelves combined with external blinds in south-facing classrooms in Athens, Greece. Energy and Buildings. 2016;116:190-205.

[24] Lim Y-W, Ahmad MH, Ossen DR. Internal shading for efficient tropica daylighting in Malaysian contemporary high-rise open plan office. Indoor and Built Environment. 2013;22(6):932-51.

[25] Kischkoweit-Lopin M. An overview of daylighting systems. Solar Energy. 2002;73(2):77-82.

[26] Beltran L, Lee E, Selkowitz S. Advanced optical daylighting systems light shelves and light pipes. Journal of the illuminating engineering society. 1997;26(2):91-106.

[27] Hashemi A. Daylighting and solar shading performances of an innovative automated reflective louver system. 2014.

[28] DeKay M, Brown G. Sun, wind, and light: Architectural design strategies: John Wiley \& Sons; 2013.

[29] Claros S-T, Soler A. Indoor daylight climate-comparison between light shelves and overhang performances in Madrid for hours with unit sunshine fraction and realistic values of model reflectance. Solar energy. 2001;71(4):233-9.

[30] Claros S-T, Soler A. Indoor daylight climate-influence of light shelf and model reflectance on light shelf performance in Madrid for hours with unit sunshine fraction. Building and Environment. 2002;37(6):587-98.

[31] Littlefair PJ. Light shelves: computer assessment of daylighting performance. International Journal of Lighting Research and Technology. 1995;27(2):79-91

[32] Soler A, Oteiza P. Light shelf performance in Madrid, Spain. Building and Environment. 1997;32(2):87-93.

[33] Berardi U, Anaraki HK. Analysis of the impacts of light shelves on the useful daylight illuminance in office buildings in toronto. Energy Procedia. 2015;78:1793-8.

[34] Ponmalar V, Ramesh B. Energy efficient building design and estimation of energy savings from daylighting in chennai. Energy Engineering. 2014;111(4):59-80

[35] Djamila H, Ming CC, Kumaresan S. Estimation of exterior vertical daylight for the humid tropic of Kota Kinabalu city in East Malaysia. Renewable Energy. 2011;36(1):9-15.

[36] Lim Y. Internal shading for efficient tropical daylighting in high-rise open plan office. Doctor of Philosophy, Faculty of Built Environment, Universiti Teknologi Malaysia. 2011.

[37] Rungta S, Singh IV. Design Guide: Horizontal shading devices and light shelves. Vipul Singh, Assignment. 2011(3).

[38] Lim Y, Mohd Hamdan A, editors. Daylight and users' response in high rise open plan office: a case study of Malaysia. 3rd International Graduate Conference on Engineering, Science, and Humanities, Universiti Teknologi Malaysia, Skudai, Johor, Malaysia; 2010.

[39] Lim Y, Mohd Hamdan A, Ossen D, editors. Effect of solar shading, fenestration and room geometry on office building energy efficiency in hot humid tropic. 3rd International Conference on Built Environment in Developing Countries; 2009.

[40] Ho M-C, Chiang C-M, Chou P-C, Chang K-F, Lee C-Y. Optimal sunshading design for enhanced daylight illumination of subtropical classrooms. Energy and buildings. 2008;40(10):1844-55.

[41] Shahriar ANM, Mohit MA. Estimating depth of daylight zone and PSALI for side lit office spaces using the CIE Standard General Sky. Building and environment. 2007;42(8):2850-9.

[42] Tzempelikos A, Athienitis AK. The impact of shading design and control on building cooling and lighting demand. Solar Energy. 2007;81(3):369-82.

[43] Wu W, Ng E. A review of the development of daylighting in schools. Lighting Research and Technology. 2003;35(2):111-24.

[44] Bülow-Hübe H. Energy Efficient Window Systems. Effects on Energy Use and Daylight in Buildings. Rapport TABK. 2001.

[45] Dubois M-C. Impact of solar shading devices on daylight quality: simulations with radiance. Division of Energy and Building Design: Lund University, Sweden. 2001

[46] Dubois M-C. Impact of shading devices on daylight quality in offices Simulations with Radiance. 2001.

[47] Murray V, O’Flynn C, Beattie K, editors. Advanced building services simulation software providing design solutions in Dublin and Boston. 7th Internation IBPSA Conference Brazil: Rio de Janeiro; 2001.

[48] Veitch JA. Psychological processes influencing lighting quality. Journal of the Illuminating Engineering Society. 2001;30(1):124-40.
[49] Mills E, Borg N. Trends in recommended illuminance levels: an international comparison. Journal of the Illuminating Engineering Society. 1999;28(1):155-63.

[50] Berrutto V, Fontoynont M, Fourmigue J-M. Effect of Temperature and Light Source Type (natural/artificial) on Visual Comfort Appraisal: Experimental Design and Setting. 1997.

[51] Robbins CL. Daylighting. Design and analysis. 1985

[52] Zain-Ahmed A, Sopian K, Abidin ZZ, Othman M. The availability of daylight from tropical skies - a case study of Malaysia. Renewable Energy. 2002;25(1):21-30.

[53] Freewan A, Shao L, Riffat S. Optimizing performance of the lightshelf by modifying ceiling geometry in highly luminous climates. Solar Energy. 2008;82(4):343-53.

[54] Freewan AA. Maximizing the lightshelf performance by interaction between lightshelf geometries and a curved ceiling. Energy Conversion and Management. 2010;51(8):1600-4.

[55] CIBSE. Code for interior lighting. In: Engineers TCIoBS, editor. London1994.

[56] Malaysia DoS. Code of Practice on Energy Efficiency and use of Renewable Energy for Non-residential Buildings, 1st Revision. In: 2014 DoSM, editor. Malaysia1525: 2014

[57] GBI. Green Building Index, Malaysia. 2013.

[58] CIE. Publication No 29.2. Guide on Interior Lighting. (2nd ed.). Vienna, Austria: Commission International De L, eclairage (CIE). 1986

[59] Dubois MC. Impact of shading devices on daylight quality in offices: simulations with radiance. Lund Institute of Technology, Department of Building Science. 2001a.

[60] Dubois MC. Impact of Solar Shading Devices on Daylight Quality: Simulations with Radiance, Report No TABK-01/3062, Division of Energy and Building Design, Lund Institute of Technology, Lund University, Lund Sweden. 2001b.

[61] IESNA. Lighting Handbook: Reference and Application. (8th ed.) Illuminating Engineering Society of North America. North America1993.

[62] Haqparast F, Maleki BA. Daylighting and daylight simulation. Int J Tech Phys Probl Eng. 2014;6(20):116-20

[63] Assaf L, editor Glare and illuminance uniformity as components of innovative glazing performance. Right Light; 1997.

[64] Fontoynont M. Perceived performance of daylighting systems: lighting efficacy and agreeableness. Solar Energy. 2002;73(2):83-94.

[65] Dubois M-C. Shading devices and daylight quality: an evaluation based on simple performance indicators. Lighting Research and Technology. 2003;35(1):61-74.

[66] Rindfleisch A, Malter AJ, Ganesan S, Moorman C. Cross-sectional versus longitudinal survey research: Concepts, findings, and guidelines. Journal of Marketing Research. 2008;45(3):261-79.

[67] Mohammed YHS. Appropriate opening and layout for daylighting of office spaces: The case of EMU faculty of architecture office building: Eastern Mediterranean University (EMU)-Doğu Akdeniz Üniversitesi (DAÜ); 2014

[68] Ossen DR. Optimum overhang geometry for high rise office building energy saving in tropical climates. 2005

[69] Steemers K. Daylighting design: Enhancing energy efficiency and visual quality. Renewable Energy. 1994;5(5-8):950-8.

[70] Lim Y-W, Heng CYS. Dynamic internal light shelf for tropical daylighting in high-rise office buildings. Building and Environment. 2016;106:155-66.

[71] Malaysia DoS. Code of Practice on Energy Efficiency and use of Renewable Energy for Non-residential Buildings. In: Department of Standards MS 1525 MS, editor. Malaysia1525: 2007

[72] Xue P, Mak C, Cheung H. New static lightshelf system design of clerestory windows for Hong Kong. Building and Environment. 2014;72:368-76 